\title{
LINGUISTIC POLICY AND THE SECURING OF NATIONAL IDENTITY IN TODAY'S SOCIETY. THE UKRAINIAN CASE
}

\author{
Ecaterina Hlihor ${ }^{1}$ \\ "Carol I" National Defence University
}

\begin{abstract}
Our study takes into consideration the consequences of the linguistic legislation adopted by Kiev in recent years in order to secure the identity of the existing national minorities. It also tackles the potential conflicts between the Ukraine and its neighbouring states with regard to the observing of the cultural rights of the minority groups. The issue of the use of regional languages fits into the category of the highly ideological and politicized matters in the Ukraine.
\end{abstract}

Keywords: linguistic policy; forced Ukrainization; identity security; regional languages; language conflict.

\section{INTRODUCTION}

The securing of national/ethnic identity has become an issue of interest on the agenda of security studies, especially after the amplification of the globalization and regional integration processes, such as in the case of the expansion of the European Union (Castells 2006; Lieber \& Weisberg 2002; Neumann 2009; Șerbu 2006). The two processes contain phenomena that are beneficial to contemporary society, but also a number of dangers pertaining to the temptation towards "levelling", homogenization or even the exercising of a linguistic imperialism in certain communities, regardless of their size. However, identity is the way through which meaning can be conveyed to people's lives at a time when modern states' reason to be may disappear. In this sense, people want more than just a market economy. Indeed, it could be said that the state is an agent of globalization, and not of people. The reaction to these is the alternative construction of meaning, based on identity (Castelles 2006). It can be achieved through policies of securing of national/ethnic identity. In contemporary society the "national existence of an ethnic group is largely conditioned by the functional status of the ethnic language. In individual speech, as far as we know, a number of significant particularities of the individual - social, psychological, linguistic - are naturally objectified" (Chemes 2012, 384). For this, it is necessary that we understand what securing is and how it can be achieved, which are the ways in which it can be achieved, to what extent the linguistic policy of a state can contribute to the (de)securing of the identity of a national majority or ethnic minority living in that particular state.

Researchers in the critical security studies, especially those belonging to the School of Copenhagen, drew attention to the fact that achieving a fully secure society requires not only an extension of this research domain, but also the identification of new concepts and notions. One of these concepts is that of securing, which describes the process through which political actors transform facts, phenomena, and processes that do not constitute existential threats to the survival or territorial integrity of the state in matters of national security and thus extraordinary measures, made in order to "cope" with those "threats", are legitimized. The conceptualization of securing as an act of speech is important because it shows us that notions/words describe not only the objective, concrete and tangible reality, but they also become a way to construct the social reality, which is neither observable not tangible, but without which society, freedom and democracy could not exist (Buzan\& Waever\& Wilde 1998, 23-26). For example, describing an immigrants camp in any Western city as a "jungle" does not mean that this term describes a concrete reality that would truly resemble an immigrants/asylum seekers camp. That camp is metaphorically defined as a place where people are

${ }^{1}$ Corresponding author: hlihor.ecaterina@myunap.net 
predisposed to illegal and thus dangerous deeds. Similarly, speaking in the current Ukrainian society of the Ukrainian language as being "trendy" does not mean that a different linguistic "trend" might be accepted in the public arena tomorrow. To the contrary. A Facebook posting by former Ukrainian president Petro Poroshenko referring to the state language on the occasion of the passing by the Parliament in Kiev on 25 April 2019 of the Law regarding the functioning of Ukrainian as state language does not leave room for the language of the enemy in Kremlin in any sphere of activity: "Let me emphasize that this law does not in any way affect any language of the national minorities living in Ukraine. We tried to take into consideration the points of view of all interested parties. The only opinion that we did not intend to consider was Moscow's. Let Moscow worry about the Russian language. We simply gave Ukrainians the right to listen to Ukrainian songs, to watch Ukrainian films, to read Ukrainian books, because people tend to do these things. The Ukrainian language is trendy. It is not, however, trendy not to know the Ukrainian language" (MC 2019).

With the help of language and through an act of speech, a threat can be constructed which could be real or only stated as such. There are two conceptual dimensions of the theory of securing. The first is linked to the criteria and modalities through which a problem can be secured. About the second we speak when we can say that a problem was successfully secured, on a scale ranging from un-politicized to politicized (Buzan\& Waever\& Wilde 1998, 23-26). The stages of a securing process are the following: first of all, there has to be a legitimate authority that presents/identifies someone or something as an existential threat to society or one of its segments; the second step - concrete measures are taken to eliminate the threat in order to protect society or one of its segments. In its turn, society or one part of it accepts the idea that something might happen to it and for this reason agrees to measures taken to protect it (Buzan \& Waever \& Wilde 1998, 25). In essence, a speaker identifying a need for securing (Peoples \& Williams 2017, 96) utters a speech through which something/someone is presented as a threat (Peoples \& Williams 2017, 95). Upon perceiving the act of speech, the population must accept the existence of the threat so that the observer/communicator might finalize the process of securing. In his studies on the processes of securing, Ole Waever believes that the communicators who identify a security problem and communicate it to the society are its political elites (Waever 1995, 55), the ones that can legitimately take securing measures. Thus, the theories accepting the linguistic construction of security issues have had a great impact on security studies. However, these theories did not come to occupy an empty spot regarding the research in the field of language constructed social reality (Balzacq \& Léonard\&Ruzicka 2016, 494-531).

\section{THE ISSUE OF LINGUISTIC IDENTITY IN THE UKRAINE}

The Ukraine, having become an independent country after the fall of the Soviet Union, is characterized as a multilingual society, an "advocate of the ideal of a multilingual and multicultural state" (Plokhy 2018, 382) in which bilingualism became the norm after 1991 (Plokhy 2018, 387). The largest minority is the Russian one, followed by several smaller ones. In its South-West (Subcarpathia, Chernowski, Bukovina) and South regions (Odessa), beside Ukrainians, a number of other minorities are present, among which Romanians (some of which identify themselves as Moldavians). According to statistics, Ukrainians compose $77.8 \%$ of the population. Other minorities include Byelorussians $0.6 \%$, Hungarians $0.3 \%$, Crimean Tatars $0.5 \%$, Romanians and Polish $0.3 \%$, Jews $0.2 \%$. Other minorities make up 1.8\%. (World Population Review 2020)

As in many other countries in the post-Soviet space, the security preoccupations - defined here as preoccupations for sovereignty, internal stability and territorial integrity - have played an important role in the government decision making process related to minorities, including here the issues of a linguistic nature.

Although not always explicitly stated, namely the fear of separatism, of secession, of disintegration of the country has shaped the perception by the Ukrainian state of the issues regarding ethnic, linguistic and religious minorities. To the extent that the Ukrainian political elite perceived such phenomena as threats to the society, a series of legislative and implicitly administrative decisions were made by the Rada. In an effort to secure the Ukrainian nation, its leaders failed to consider the fact that the measures made to secure the majority could be perceived as threats by the Hungarian, 
Romanian, Polish or Tatar minorities or by the emblematic linguistic minority of the speakers of Surzhyk (Karadeniz Press 2013). Contemptuously defining a mixture of grains - oats, barley, rye the term surzhyk describes a degraded variety of a long dominated language, Ukrainian, appeared in an attempt by its speakers to more closely resemble the dominating, exemplary language, Russian (Bivolaru 2016, 74-87). Such a paradoxical situation, in which the majority of Ukrainians were forced to "swallow their tongue" (Golopentia 2009, 10-13) in their own territory for centuries on end, led to a linguistic conflict. It is not therefore surprising that analysts and theoreticians often connect a growing ethnic, linguistic and national identity to the aggravation of ethnic and linguistic conflicts in certain situations (Posen 1993, 27-47).

The existence of linguistic conflicts is far from unique, specific only to the Ukraine (recent years conflicts in Catalonia speak for themselves), they are in fact the "norm" in political communities where language acts as a marker of identity (Arel 2018, 233-264) and where the majority does not respect the linguistic rights of minorities. Our working hypothesis for this study is that, following the annexation of Crimea by the Russian Federation in 2014, the issue of national minorities in the Ukraine was included in the security policy as a potential source of danger to national stability and identity. This main problem refers to the process of securing and de-securing of states, as it as defined by Barry Buzan (Buzan 1997, 5-28). In the international environment, one characterized by change, we observe a re-conceptualization of the notion of security, including new issues related to threats and risks to state stability, including the linguistic and identity ones, as a consequence of the emergence of the new generation warfare, namely the hybrid warfare. Furthermore, security problems are shifted from state/society level to the level of region of a state, including the level of communities and individuals.

After the political and geopolitical events known in specialty literature under de name of Euromaidan when, under the pressure of protests, the Ukrainian president Viktor Yanukovych fled to Russia and power was seized by pro-Western forces, a growing number of analysts, politicians, journalists, independent observers in the European Union, and in Romania as well, expressed their hope that the new Ukrainian leadership will choose the European vector of development, which includes among other things a wide range of national minority rights (Gherman 2018, 17), a hope further fuelled by the fact that the Ukraine signed in 1996 and ratified in 2005 the European Charter for Regional and Minority Languages.

As proved by the political and social evolution of the last decades, and especially of the last years, things did not follow a desired path and the sharing of the linguistic good has become a "hot" issue in the Ukraine. According to article 10 of the Constitution, the official language of the country is Ukrainian. The same article guarantees the free development, use and protection of the Russian language and of the languages of other national minorities (Patras 1999). The Law of Culture of 2011 states that the "State ensure the comprehensive development and functioning of the national language of cultures in the Ukraine, it promotes the creation of the internal (national) cultural product in the Ukrainian language and its popularization in Ukraine and abroad; the use of other languages is guaranteed within the sphere of culture" (Patras 1999).

According to the 2001 census, $67.5 \%$ of the population consider the Ukrainian language is their mother tongue, while $29.6 \%$ name Russian as their mother tongue. According to social monitoring studies conducted by the Institute of Sociology of the National Academy for Sciences, the official language is used in daily communication by $42 \%$ of families, Russian by $36 \%$ and other languages by $21 \%$, as can be observe din the image below: 


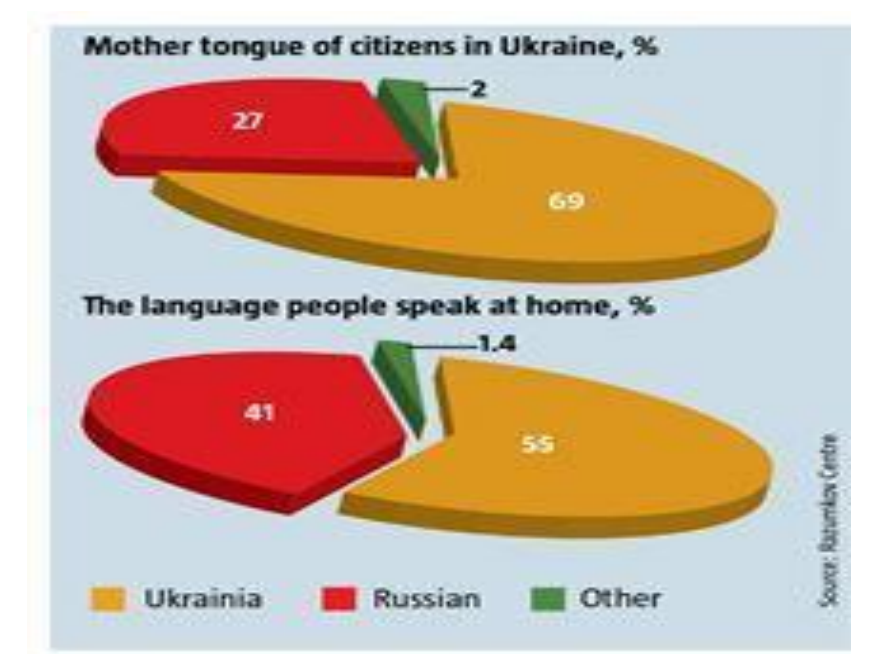

Source: Ukraine/ 4.2 Specific policy issues and recent debates, online https://www.culturalpolicies.net/web/ukraine. php?aid=425

\section{HOW THE LINGUISTIC POLICY IN UKRAINE BECAME AN SECURITY ISSUE AND ITS INFLUENCE ON REGIONAL STABILITY}

Specialists in the field of security studies and policies, but not only, searched for solution to find an adequate action model at political and military level in order to eliminate the threats to nationals security from the Ukrainian society. Among these there was a group of Ukrainian political scientists and historians led by Volodimir lablonski and Serhii Zdioriuk, who received a research project from the National Institute of Strategic Studies, financed by the government in Kiev (Gherman 2018, 17). The result of their work constituted the foundation for a monograph, Ukraine and the Russian World Project, which provides several recommendations to state institutions, such as the Presidency and the Parliament. One of these recommendations envisaged the countering of the influence of the Russian Federation over Ukraine. The practical modality to achieve this was to identify ways to reduce the dependency of the Ukrainian society on the Russian language (Gherman 2018,18 ). Thus, in the opinion of the authors, Russian schools in the Ukraine are one element in the promotion of this language. The "logical" consequence is that Russian is regarded as a danger/threat to the Ukrainian state. The identification of the Russian language as a threat to Ukrainian identity and security was also enhanced by the launching of the geopolitical concept "Russian World" project by the Patriarch of the Russian Orthodox Church, Kiril, on 3 November 2009 ("Russkyi Mir") (Pieper 2017). In fact, the high priest revitalized an older idea expressed by the leader in Kremlin, Vladimir Putin who in 2007 stated that "the Russian world can and must unite all those who love the Russian word, the Russian culture, no matter where they might live, in Russia or beyond" (Gherman 2018, 18). This project includes three elements: the Orthodox religion, the Russian language, and the commune historical memory. The Patriarch Kiril further explained that Russia, Ukraine and Belarus must compulsorily participate in this project.

According to research carried out by Marin Gherman, after the annexation of Crimea by Russia the experts of the National Institute for Security Studies in Kiev recommended to the Ukrainian state power the following: 1) the regulation of the information space by introducing linguistic quotas in the audiovisual media, which was put into practice in the summer of 2017 and which had a negative impact on Romanian language media as well; 2) the education of the majority of children in the state language, an aspect which is mentioned in the new Law of Education passed in September 2017; 3) the formulation of an own national ideology as an alternative to the "Russian World" geopolitical project (Gherman 2018, 18). The creation of a geopolitical project of the "Ukrainian World" can be a solution to eliminate the threat generated by the "Russkyi Mir" concept, but it can also constitute at the same time a threat to the linguistic identity of Ukrainian's national minorities! We have to deal here with a double process of securing and de-securing taking place in the Ukrainian society. Aiming to reduce Russia's influence, Kiev believes it necessary the challenge the pillars of the "Russian World": 
mass-media, the Russian school and the Russian Church. AN attack on these three elements collaterally attacks the identity elements of all national minorities and communities, including the Romanian one (Gherman 2018, 20).

The rational solution can only be to respect the rights and freedoms of all Ukrainian inhabitants by adopting a linguistic policy adequate to a multilingual society and to a lesser degree by way of futuristic geopolitical projects (mirroring that of the Russian Federation) which do nothing but preserve the linguistic rifts in the West and South-East of the country. Until the annexation of Crimea and the beginning of the hybrid war at the Eastern border, researchers of Ukrainian linguistic policy believed that the linguistic legislation in the country was sufficient and non-restrictive for the development of linguistic diversity, as Russian and other minority languages were constantly used in most of activities in the public sphere (Stepanenko 2003, 115). Problems arose after Euromaidan and after the Ukrainian president signed on 25 September 2017 a controversial law which made the Ukrainian language a compulsory subject in all state schools beginning with the fifth grade (Radio free Europe, Radio Liberty 2017).

Fears related to the loss of ethnic identity were heard in the Ukrainian society by way of petitions by national minority representatives addressed to the president in power, Petro Poroshenko, and asking him no to sign the "Law regarding the functioning of the Ukrainian language". His answer to these requests showed indifference and ill faith: "I emphasize that this law does not infringe the languages of the national minorities in Ukraine" (Ukrainskie Radio 2019). Hennadiy Moskal, the governor of Zakarpattia Oblast, with a significant Hungarian community, was one of the most vocal critics of this legislative act, claiming that it violates the European Charter for Regional and Minority Languages. Yaroslav Halas, spokesperson of the governor of Zakarpattia Oblast, expressed what some critics suspect to be exactly the purpose of this law. "This law envisages protecting the Ukrainian language, but it is especially aimed against the Russian language because this latter one dominates the capital and the regions in the East. Its purpose is not to protect the 150.000 Hungarians or couple of tens of thousands Romanians, who live in the Chernivtsi region or in the Odessa region, where there many Moldavians or Gagauzi"; "...in Transcarpathia this law hits the national minorities." (Ukrainskie Radio 2019).

The authorities in Kiev, in an attempt to secure the identity of the majority through linguistic policies that do not take into account the ethnic structure of the society, created huge problems of identity security to ethnic minorities who perceive themselves as discriminated and in danger of losing their identity. Alexandrina Cernov observed the effects that the law of 2017 regarding the status of the Ukrainian language might have on the Romanian minority: "Beside the grand propaganda in favour of the Ukrainian language, I believe that an attempt is carried out to eliminate other languages from communication, because there are laws that impose on us to communicate less and less in our mother tongue. Consequently, these attempts to eliminate the mother tongue from communication impose logical reactions from parents who think of their children's future prospects." (Cernov 2019, 5) These natural identity defence reactions inevitably lead to tensions at the level of the relations between the state and minorities. Referring to this aspect, professor Marian Gherman claimed that the "attempt by ethnic Romanians to defend themselves by way of old methods, as those used before the Russo-Ukrainian confrontation, when the new geopolitical challenges were invisible, is seen by Kiev as an act of betrayal and secession, which determined a distancing between centre and periphery, between leadership and ethnic groups - a situation never experienced before" (Gherman 2019, 3). In these circumstances, the Ukrainian society may slide towards national extremism, which prevents the achievement of a democratic legislation that is adequate to minorities. As the history of the Balkans and of the post-Soviet society in Ukraine's proximity, and not only, demonstrated, after the end of the Cold War the nationalist manifestations are aimed against the enlargement of national minority rights. The Romanian minority in this country has perceived itself as such beginning with 2017 . We fin this perception especially among specialists, but not exclusively. Alexandrina Cernov observed the attempt to marginalize and disrespect the Romanian minority long before the passing of this recent legislative linguistic policy act: "Romanians are described as enemies of Ukraine. Attempts to accuse Romania and the Republic of Moldova are observed daily in the Ukrainian mass-media and on the 
internet. It is easy to find reasons: either that Romania is preparing for war against Ukraine (there is even discussion of three possible locations of a possible war: an air and maritime one at the Black Sea, on the Danube in Ismail or in Bukovina); or the double citizenship which could negatively impact Ukraine especially in Bukovina where the populations is willing to obtain Romanian citizenship; or the little aid that Romania offers in order to help Romanian culture in Ukraine, all qualified as direct interference by Romania in Ukrainian policy" (Cernov 2019, 5). Authors like Anthony Giddens believe that "ethnic minorities are still perceived as threats by any people", such fear deriving from the fact that minorities have constantly been used as scapegoats for any society failure (if we have in mind here Western Europe) (Giddens 2001, 260).

The "threat" posed by ethnic minorities cannot be overlooked, because attributes like language, history (regardless of the imaginative degree), religion, outfit, traditional crafts "are very actual in everyday life". According to Giddens, of all these identity attributes, language is the most significant and important, because "none of us invents the language learned in childhood and we are all obliged to observe the permanent rules of usage of the linguistic method" (Giddens 2001, 52).

In June 2017 a group of parliamentarians forwarded to the Rada the project of the Law regarding the status of the Ukrainian language, in which it is stated that Ukrainian is the state (official) language. It also states the creation by the National Committee for Linguistic Standards of centres of examination that will provide public functionaries with certificates stating their linguistic skills. Petro Porosenke signed the measure on 25 September, after days of criticism especially coming from ethnic minorities.

The law does not exclude education in other languages; pupils may continue to study their own mother tongue. In the over 15000 schools in Ukraine, according to the data of the Ukrainian Ministry of Education, the Russian language is used as primary language in 581; Romanian in 75; Hungarian in 71; Polish in 5. Approximately 400,000 children are enlisted in these schools (Wesolowsky 2017).

\section{MEANINGS OF NATIONAL IDENTITY IN OF UKRAINE}

There is a growing number of opinions in the Western regions of the country according to which it would be beneficial to develop a state along the exclusively Ukrainian linguistic lines, accompanied by an intense process of "De-Russification" in the East and South of the country. Thus, the inhabitants of these regions, who do not believe that Russia develops a policy of linguistic and cultural "Russification", asked for the preservation of the Oriental/Russian Slave identity, as it was promoted during the Soviet Union. In spite of this, when this simplistic dichotomy is placed under scrutiny, the self identification by people as Ukrainian becomes more complex, because many citizens perceive themselves somewhere in-between these two cultural and linguistic poles. A large number of Ukrainians are comfortable using both languages and usually use one of them in their professional activity and the other in their private lives. This is further complicated by the presence of communities of Hungarians, Romanian, Bulgarians, and Tatars in Crimea (at least until the illegal annexation of the peninsula in 2014). The vast majority of those identifying themselves as members of these communities keep their mother tongues for their private lives rather than totally introduce the official language in their everyday lives.

Against this diverse ethnic-cultural and linguistic background, the public efforts of Vladimir Putin to reformulate the institutional perception of the Russian nation following his re-election as president in 2012 have had profound consequences in Ukraine. Putin resuscitated the concept of "Russkyi Mir" (Socor 2014), one long used by Russian ultra-conservative circles to describe a Russian cultural and linguistic space that expands beyond the borders of the Russian Federation. The "defence" of the "Russkyi Mir" served as a pretext for the annexation of Crimea and the invasion of Donbas in South-East Ukraine. The idea itself attempts to undermine the Ukraine by dividing the country between Ukrainophones and Russophones.

Unexpectedly, Russia's military actions, accompanied by this narrative, accelerated the incomplete process of Ukrainian nation building. Thus, the great regions of the country chose to reject the notions of ethnic identity specific to the XIX century and based on common history, culture and 
language, in favour of a more inclusive civic identity constructed on the respect for values, rights and common citizenship. This aspect was observed by sociologist Stuart Hall who states that civic identity only through a relationship with the other, with what I am not in relation to the other. It results from this that the Ukrainian identity is a socially constructed one (Stuart 2015, 3-4), which never happened in the political space of the Tsarist Empire and of the Soviet Union. Centuries of Russian imperial assimilation sought to reduce the Ukrainian culture from an independent entity to a simple regional denotation. The consequences of this fact are seen nowadays in the struggle among the politicians in Ukraine for the conservation of identity.

The aggression by the Russian Federation in Donbas gave politicians the opportunity to intensify the identity discourse in terms if a security problem. Regardless of what Russian media say to inhabitants in Eastern Ukraine, the humanitarian crisis, the people affected by civil war are impossible to ignore. According to the Centre for Monitoring of Internal displacement, as a consequence of the conflict, the number of displaced persons reached 1.65 million at the beginning of 2016. This is the way in which a linguistic issue can generate a humanitarian crisis, creating a major problem at the level of the entire Ukrainian society.

\section{CONCLUSIONS}

After the annexation of Crimea and the aggression in Donbas by the Russian Federation, for reasons of national identity security, Ukraine adopted a number of measures towards DeRussification. By changing the linguistic legislation, as a result of the passing of a new law in September 2017, the aim was to consolidate the role of the Ukrainian language in society and the reduction of the role of the Russian language in school education in the South-Eastern regions of the country. This fact led, on the one hand, to the Ukrainianization of the public space, mass-media, administration and education system, and on the other hand to the restriction of the rights of national minorities to use their own languages in the education system. The consequence of these measures is the identity de-securing of the ethnic minorities in the Ukrainian society. The requests by Russian, Romanian, Tatar, Roma, Hungarian etc. ethnic groups with regard to these restrictions were ignored, being considered hysterical, exaggerated and unfounded. The reasons, regardless of how well reasoned and justified by the authorities in Kiev, can not replace the authentic fears of minorities regarding the security of their national identities and the observance of their civil rights.

\section{REFERENCES}

Arel, Dominique. 2017-2018. Language, Status, and State Loyalty in Ukraine, in Harvard Ukrainian Studies, Vol. 35 No. 1-4. Accessed February 12, 2021. https://www.husj.harvard.edu/articles/ language-status-and-state-loyalty-in-ukraine

Balzacq, Thierry, Léonard, Sarah, Ruzicka, Jan. 2016. 'Securitization' revisited: Theory and cases. International Relations. Vol. 30, issue 4.

Bivolaru, Aliona. 2016. Tendințe în lexicul limbii ucrainene actuale. Editura Universității din București.

Buzan, Barry. 1997. Rethinking Security after the Cold War, Cooperation and Conflict, Vol. 32, No. 5.

Buzan, Barry, Waever, Ole, Wilde, Jaap de. 1998. Security: A New Framework for Analysis, Lynne Rienner Pub.

Castells, Manuel. 2006. Globalisation and identity. A comparative perspective: Transfer. Accessed February 18, 2021. https://lull.cat/IMAGES_175/transfer01-foc01.pdf

Cernov, Alexandrina. 2019. Suntem revoltați de modul în care este implementată politica lingvistică din Ucraina. BucPress. Revistă de gândire românească din Cernăuți, nr. 1, 5.

Chemes, Valerii Fedorovych. 2012. Identitatea etnolingvistică a persoanelor de origine ucraineană/rusă în mediul românofon din regiunile polietnice ale Ucrainei, in Studia Linguistica. Випуск 6/2012 
Gherman, Marin. 2018. Românii din nordul Bucovinei: între concepția „lumii ruse” și noua concepție a „lumii ucrainene”, Glasul Bucovinei/The Voice Of Bukovina, Chernivtsi - Bucharest, No.3, Year XXV, No. 99.

Gherman, Marin. 2019. „Românii din Ucraina în «menghina geopolitică»”. BucPress. Revistă de gândire românească din Cernăuți nr. 1.

Giddens, Anthony. 2001. Sociologie. Translated by Oana Gheorghiu. București: Bic All.

Golopenția, Sanda. 2009. Româna globală. București: Fundația culturală Secolul 21.

Hall, Stuart. 2015. Introduction: Who Needs "Identity"?. Questions of Cultural Identity, Stuart Hall and Paul du Gay, London: Sage Publications.

Karadeniz Press. 2013. "Limba surjik", propusă drept limbă oficială a Ucrainei. Accessed February 18, 2021. https://karadeniz-press.ro/limba-surjik-propusa-drept-limba-oficiala-a-ucrainei/

MC. 2019. Petro Poroşenko a promulgat legea care consolidează statutul limbii ucrainene, Rador, 16 mai 2019. Accessed February 18, 2021. https://www.rador.ro/2019/05/16/petro-porosenko-apromulgat-legea-care-consolideaza-statutul-limbii-ucrainene/

Neumann, Victor. 2009. „Globalizarea sau orientarea noii diversităţi culturale”. Revista Vestul. Tribună a Demnităţii Bănăţene. Accessed February 18, 2021. .http://www.vestul.ro/stiri/ 1022/globalizareasau-orientarea-noii-diversitati-culturale.htm

Patras, Eugen. 1999. Minoritatile nationale din Ucraina si Republica Moldova Statutul juridic. Editura Alexandru cel Bun Cernauti.

Peoples, Columba, Vaughan-Williams, Nick. 2017. Critical Security Studies. An Introduction 2nd Edition, Routledge.

Plokhy, Serhii. 2018. Porțile Europei. O istorie a Ucrainei. Translated by Smaranda Câmpeanu. București: Editura Trei.

Posen, Barry R. 1993. The Security Dilemma and Ethnic Conflict Survival volume 35, issue 1. Accessed February 20, 2021. http://www.rochelleterman.com/ir/sites/default/files/posen1993.pdf

Pieper, Moritz. 2018. Russkiy Mir: The Geopolitics of Russian Compatriots Abroad. Geopolitics. https://www.tandfonline.com/doi/abs/10.1080/14650045.2018.1465047?journalCode=fgeo20

Radio Free Europe, Radio Liberty. 2017. Ukrainian President Signs Controversial Language Bill Into Law. Accessed February 18, 2021.https://www.rferl.org/a/ukrainian-poroshenko-signscontroversial-language-bill-into-law/28757195.html

Socor, Vladimir. 2014. 'Putin Inflates "Russian World" Identity, Claims Protection Rights'. The Jamestown Foundation. Accessed February 20, 2021. https://jamestown.org/program/putininflates-russian-world-identity-claims-protection-rights/

Stepanenko, Victor. 2003. Identities and Language Politics in Ukraine: The Challenges of NationState Building, in F. Daftary, F. Grin, eds., Nation-building, ethnicity and language politics in transition countries. Budapest: Open Society Institute.

Şerbu, Gheorghe M. 2006. Globalizare şi identitate naţională: Simpozion. București: Editura Ministerului Administraţiei şi Internelor.

Ukrainskie Radio. 2019. Președintele Ucrainei Petro Poroșenko a semnat legea „Cu privire la funcționarea limbii ucrainene". Accessed February 18, 2021. http://www.nrcu.gov.ua/ ro/news.html?news $\mid \mathrm{D}=87359$ 
Waever, Ole.1995. Securitization and Desecuritization, in Ronnie D. Lipschutz, ed., On Security, New York: Columbia University Press.

Wesolowsky, Tony. 2017. Ukrainian Language Bill Facing Barrage Of Criticism From Minorities, Foreign Capitals, Radio Free Europe. Accessed February 21, 2021. https://www.rferl.org/ a/ukraine-language-legislation-minority-languages-russia-hungary-romania/28753925.html

World Population Review. 2020. Accessed February 18, 2021. http://worldpopulationreview.com/ countries/ukraine-population/ 